\title{
TITLE:
}

\section{Constitution of the Mahale Wildlife Conservation Society}

$\operatorname{AUTHOR}(\mathrm{S})$ :

\section{CITATION:}

Constitution of the Mahale Wild life Conservation Society. Pan Africa News 1995, 2(1): 5-7

ISSUE DATE:

1995-06

URL:

http://hdl.handle.net/2433/143315

\section{RIGHT:}

Copyright (C) Pan Africa News. 


\title{
Constitution of the Mahale Wildlife Conservation Society
}

\author{
PREAMBLE \\ This document is the CONSTITUTION of the MAHALE WILDLIFE CONSERVATION SOCIETY and is hereinafter \\ referred to as the "CONSTITUTION".
}

\author{
Article 1 \\ Name of the Society
}

The name of the Society shall be MAHALE WILDLIFE CONSERVATION SOCIETY.

Article 2

Permanent Residence of the Society

The registered office of the Society shall be in Dar es Salaam, Tanzania.

\section{Article 3}

\section{Objective of the Society}

The objectives for which the Society is established are:

1. To promote research on primates and their conservation in Tanzania, in particular the Mahale area in Western Tanzania where chimpanzees and other primates are found in the wild, attracting both researchers and tourists from all over the world.

2. To promote the conservation of the remaining natural forests in the Mahale area that form important habitats for nonhuman primates.

3. To serve as an organ that will bring together primate researchers - both novices and established authorities, forest ecologists, conservationists and general public to share their views about primates and their conservation.

4. To work with other non-government organisations in raising funds and dispersing them towards research and conservation of non-human primates and their habitats in the area of Mahale.

5. To assist its members in identifying suitable training opportunities in the country and overseas.

6. To assist its members both within Tanzania and overseas in identifying suitable research topics.

7. To establish and maintain in the Mahale area facilities that will be made available in supporting field researchers and conservationists in Tanzania.

8. To act as a link between wildlife researchers and conservationists on one hand and Government institutions on the other hand, in achieving optimum cooperation in their efforts to develop the wildlife resources in the natural forest of the country.

9. To promote public involvement in the conservation of primates and their habiat in the Mahale area by cooperating with similar non-government organisations and the government in organising public education programmes.

10. To collaborate with, and when appropriate to offer assistance to, other organisations and workers in closely related fields, namely: primate research, wildlife research and conservation within Tanzania, and any activities with a strong local connection to the Mahale area.

11. To do all such things as are incidental or conducive to the attainment of the above objectives.

\section{Article 4}

\section{Membership}

Membership of the Society shall be of two types, namely:

1. Ordinary Membership: This type of membership of the Society shall be open to individuals and to variously constituted bodies involved in or wishing to support the objectives of the Society.

2. Honourary Membership: This type of membership of the Society may be conferred on any persons or institution whom in the Society's view has made significant contribution towards the advancement of its objectives provided that such person or institution consents to be conferred such membership.

3. Election to Honourary Membership shall be done at the recommendation of any member presented at the General Meeting. Such members shall hold membership for a period of three calendar years and shall be eligible for re-election. 
4. The Society shall issue membership regulations and modify them from time to time as required. Such regulations shall include but not be limited to membership requirements, classes of membership, membership obligations and members' subscriptions.

5. Members of the Society shall be required to pay membership fee as will be determined by the Society from time to time. A fully paid-up member of the Society shall be known as an "Active Member".

\section{Article 5}

\section{Office Bearers}

1. There shall be the Executive Committee consisting of:
i. The Chairman
ii. The Co- Chairman
iii. The Executive Secretary
iv. The Treasurer
all of whom shall be active members of the Society.

a. The Executive Committee shall be responsible for the implementation of the Society's aims, policies and decisions, and for this purpose shall be collectively responsible to the Society.

b. The Executive Committee shall be responsible for the day-to-day running of the Society in accordance with this Constitution.

c. Every officer shall be required to give a report of his/her activities at the Annual General Meeting of the Society.

\section{Duties of individual Officers:}

\section{a.The Chairman}

i. Shall be responsible for the general direction of the affairs of the Society.

ii. Shall be empowered to take emergency action, subject to such action being reported to the Executive Committee at the first possible opportunity, for its approval or overruling.

iii. Shall be the spokesperson of the Society and in that capacity, shall be empowered to make statements after consultation with a quorum of the Executive Committee.

iv. Shall prior to leaving office prepare and present to the Annual General Meeting a full and signed statement of the Society's account(s).

\section{b. The Co-Chairman}

i. Shall promote activities of the Society.

ii. Shall preside at the meetings of the Society in the absence of the Chairman.

c. The Executive Secretary

i. Shall be responsible for coordinating the day-to-day running of the Society.

ii. Shall handle and keep a proper record of all correspondance of the Society.

iii. Shall record, prepare and keep minutes of all committee and General Meetings of the Society.

iv. Shall be responsible for all financial transactions of the Society.

d. The Treasurer

i. Shall ensure that proper accounts are kept which are available for inspection at the request of the

Chairman, two-thirds of active members or a quorate meeting of members.

ii. Shall be accountable for any loss of monies from the Society's account(s).

iii. Shall, prior to leaving office, prepare and present to a General Meeting a full and signed statement of the Society's account(s).

3. Elections and Tenure of Office.

i. Elections for the Executive Committee shall be held at the Annual General Meeting of the Society.

ii. Only "active members" as defined in this Constitution, shall be eligible to stand and vote in an election.

iii. At least seven (7) clear days written notice of the election shall be given to all members.

iv. Voting shall be by a show of hands, unless a majority of the active members request a secret ballot.

v. The elections shall be conducted by a Returning Officer, who shall be elected by the active members present, and who shall not be a member of the outgoing committee. The Returning Officer shall have no vote except as provided for herein.

vi. In the event of a tie for any post, there shall be a second and secret ballot, after the candidates have been 
informed. If there is still a tie the returning Officer shall have the casting vote.

vii. Those elected to the Committee shall hold office for Two Calendar Years but any member of the Committee may seek re-election.

\section{Article 6 \\ Meetings of the Society}

\section{Committee Meetings}

There shall be a committee meeting as often as required, but at least once in every four calendar months. Three members of the Committee shall constitute a quorum.

\section{General Meetings}

a. There shall be an ordinary General Meeting of the Society at least once in each Calendar Year.

b. At this meeting, the Chairman shall present a report on behalf of the Committee and members of the Committee may deliver oral reports on their activities. Assembled members of the Society may comment on the overall policy of the Society and any other business.

c. An extra-ordinary General meeting shall be convened at any time by the Secretary, at four (4) days written notice to all members on a resolution of the Committee or through a request signed by at least $20 \%$ of active members of the Society.

d. Any action of the Committe in the name of the Society may be disputed or overruled by a majority of the active membership present at a General Meeting.

e. Fifteen active members, or one quarter (1/4) of all active members, whichever is the lesser, shall constitute a quorum at General Meetings. If a quorum at a General Meeting is not achieved the meeting shall be re-advertised to all members for the following week. If the second meeting is again inquorate, business shall go ahead as if a quorum had been achieved.

\section{Article 7 \\ Finance}

1. The Committee shall be collectively responsible for the Society's financial solvency.

2. All expenditure shall be authorised by a quorate committee meeting, at which the Treasurer shall be present.

3. The Treasurer and the Chairman shall be signatories of the Society's account(s). The Secretary may sign in the absence of the Chairman.

4. Annual membership subscriptions shall be fixed by the Committee as circumstances dictate.

5. The Committee may take donations from Society funds to causes deemed worthy by it, but such a decision shall not take effect until ramified by a General Meeting.

\section{Income and Properties}

1. The Society shall be empowered to receive grants and donations from individuals and bodies, and shall be required to utilise these grants in furtherance of its objectives.

2. The income and property of the Society wherever so derived, shall be applied solely towards the obejectives of the Society as set forth in the Constitution of the Society and no portion thereof shall be paid or transferred directly by way of dividends, bonuses or otherwise howsoever to the persons who at any time are or have been members of the Society. Provided that members of the Society shall be eligible in using the services of their Society to enable them to carry out projects approved by it within the limits of its objectives.

\section{Article 8}

\section{Alternations to the Constitution of the Society}

Any proposed amendment of this Constitution shall require a two-thirds (2/3) majority of a quorate General Meeting. Advance notice of at least seven (7) days for such a proposal must be given to all members in writing.

\section{Article 9}

This Constitution shall come into force after it has been read and accepted by the majority of a quorate meeting of founding members and whose names shall appear in the minutes of that meeting. 